H. E. HO, Y. ISHIKAWA, N. ASAO, Y. YAMAMOTO, T. JIN* (TOHOKU UNIVERSITY, SENDAI, JAPAN AND DALIAN UNIVERSITY OF TECHNOLOGY, P. R. OF CHINA)

Highly Efficient Heterogeneous Aerobic Cross-Dehydrogenative Coupling via C-H Functionalization of Tertiary Amines Using a Nanoporous Gold Skeleton Catalyst

Chem. Commun. 2015, 51, 12764-12767.

\section{Aerobic Cross-Dehydrogenative Coupling with Nanoporous Gold}<smiles>[2H]CCCCCC1C(C[N+](=O)[O-])CCCN1Pc1ccccc1</smiles>
(99\% yield): method B, r.t.<smiles>O=[N+]([O-])CC1c2ccccc2CCN1Cc1ccccc1</smiles>

$98 \%$ (99\%) yield: method $\mathrm{A}$<smiles>c1ccc(N2CCc3ccccc3C2c2c[nH]c3ccccc23)cc1</smiles>

$62 \%$ yield: method $\mathrm{A}$<smiles>O=[N+]([O-])CC1CCCN1c1ccccc1</smiles>

$70 \%$ yield: method $B$
95\% (99\%) yield: method $\mathrm{A}$ ( $85 \%$ yield): method $B$, r.t.<smiles>[R]C([1H])N([R])C</smiles>
up to $98 \%$ isolated yield (24 examples)<smiles>COc1ccc(N2CCc3ccccc3C2C[N+](=O)[O-])cc1</smiles>

$74 \%$ (99\%) yield: method A ( $79 \%$ yield): method B, r.t.<smiles>CC(C1c2ccccc2CCN1c1ccccc1)[N+](=O)[O-]</smiles>

$75 \%$ yield, $1: 1.7 \mathrm{dr}$, (99\% yield): method $\mathrm{A}$ ( $99 \%$ yield): method B, r.t.<smiles>N#CC1c2ccccc2CCN1c1ccccc1</smiles>
$82 \%$ yield: method $A$<smiles>COC(=O)C(C(C)=O)C1CCCN1c1ccccc1</smiles>

$52 \%$ yield: method $B$
$(\mathrm{NuH}=\mathrm{TMSCN})$<smiles>O=[N+]([O-])CC1c2ccccc2CCN1c1ccc(C(F)(F)F)cc1</smiles>

$90 \%$ (94\%) yield: method $\mathrm{A}$ (48\% yield): method $B$, r.t.<smiles>CC(=O)C(C(C)=O)C1c2ccccc2CCN1c1ccccc1</smiles>
$85 \%$ yield: method $\mathrm{A}$<smiles>CN1CCc2ccccc2C1C[N+](=O)[O-]</smiles>

$80 \%$ (96\%) yield: method $\mathrm{A}$<smiles>O=C(CC1c2ccccc2CCN1c1ccccc1)c1ccccc1</smiles>

$85 \%$ yield: method $A$ (97\% yield): method B, r.t.<smiles>CCOC1c2ccccc2CCN1PN</smiles>

$85 \%$ yield: method $A$<smiles>CCOC(OCC)C1CCCN1Pc1ccccc1</smiles>

$52 \%$ yield: method $\mathrm{B}$<smiles>O=[N+]([O-])CC1CCCCN1P</smiles>

$66 \%$ yield: method $\mathrm{B}$<smiles>COc1ccc(N(C)CC[N+](=O)[O-])cc1</smiles>

NMR yields are shown in parentheses
$70 \%$ yield: method $\mathrm{B}$

\section{Category}

Polymer-Supported Synthesis

\section{Key words}

nanoporous catalysts

gold

crossdehydrogenative coupling

tertiary amines

aerobic conditions

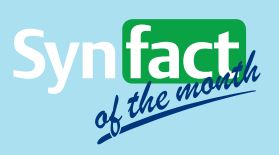

Significance: Zero-valent nanoporous gold (AuNPore) catalyzed the cross-dehydrogenative coupling of tertiary amines with carbon nucleophiles in the presence of oxygen or tert-butyl hydroperoxide to give the corresponding $\mathrm{C}-\mathrm{C}$ coupling products in $\leq 98 \%$ isolated yield (eq. 1; 24 examples). After the reaction, the catalyst was recovered by filtration and reused nine times without loss of catalytic activity.

SYNFACTS Contributors: Yasuhiro Uozumi, Takao Osako Synfacts 2015, 11(11), 1215 Published online: 19.10.2015 DOI: 10.1055/s-0035-1560664; Reg-No.: Y12115SF
Comment: The authors previously reported the preparation of AuNPore (J. Am. Chem. Soc. 2012, 134, 17536). The catalytic activity of AuNPore for the cross-dehydrogenative coupling was superior to that of other nanoporous metal catalysts, such as nanoporous silver, copper, palladium, or platinum. An SEM study revealed that the morphology, pore size, and nanoporosity of AuNPore were unchanged after the catalytic reaction. ICP-MS analysis of the reaction solution showed no leaching of gold from the catalyst. 